\title{
Efektivitas Sugar Dressing (100\% Gula) dalam Meningkatkan Kepadatan Kolagen pada Proses Penyembuhan Luka Bakar Buatan pada Kulit Tikus Putih (Rattus norvegicus) Jantan
}

\author{
(EFFECTIVENESS OF SUGAR DRESSING (100\% SUGAR) IN IMPROVING \\ COLLAGEN DENSITY IN THE WOUND HEALING PROCESS AFTER ARTIFICIAL \\ BURN INJURY IN ALBINO RATS (Rattus norvegicus) SKIN)
}

\author{
Angela Swasti Ivanalee ${ }^{*}$, Ira Sari Yudaniyanti², Maya Nurwartanti Yunita ${ }^{3}$, Nusdianto \\ Triakoso $^{2}$, Iwan Sahrial Hamid ${ }^{4}$, Amung Logam Saputro ${ }^{2}$ \\ ${ }^{1}$ Bachelor of Veterinary Medicine, \\ ${ }^{2}$ Department of Clinic and Animal Hospital, \\ ${ }^{3}$ Department of Veterinary Microbiology, \\ ${ }^{4}$ Department of Basic Veterinary Science, \\ Faculty of Veterinary Medicine, Universitas Airlangga, \\ UNAIR C-Campus Mulyorejo, Surabaya, Jawa Timur, Indonesia, 60115 \\ Telp. (031)5993016, Fax. (031)5993015 \\ *Corresponding author: a.swasti.ivanalee-2014@fkh.unair.ac.id
}

\begin{abstract}
Abstrak
Luka bakar merupakan hilangnya atau rusaknya keutuhan kulit akibat paparan suhu atau pH, zat kimia, gesekan, trauma tekanan dan radiasi. Proses penyembuhan luka tidak lepas dari peran kolagen. Sintesis kolagen dapat dipromosikan melalui pemberian gula (sugar dressing). Tujuan penelitian ini adalah mengetahui efektivitas sugar dressing untuk meningkatan kepadatan kolagen dalam proses penyembuhan luka bakar buatan pada kulit tikus putih (Rattus norvegicus) jantan. Dua puluh ekor tikus putih (Rattus norvegicus) jantan dibagi menjadi lima kelompok dengan jumlah empat ekor tiap kelompok. Kelompok K- (kontol negatif) tidak diberi perlukaan. Kelompok $\mathrm{K}+$ (kontrol positif) di beri perlukaan kemudian hanya diberi bilasan $\mathrm{NaCl}$ fisiologis. Kelompok P1 (Bioplacenton ${ }^{\circledR}$ ) diberi perlukaan dengan pengobatan Bioplacenton ${ }^{\circledR}$. Kelompok P2 (sugar dressing) diberi perlukaan dengan pengobatan gula dan P3 (madu) menggunakan madu sebagai obat. Perawatan diberikan setiap hari sekali selama empat belas hari. Hasil uji nonparametrik Kruskal-Wallis menunjukkan perbedaan yang signifikan $(\mathrm{p}<0,05)$ dan dilanjutkan dengan uji beda Mann-Whitney. Kepadatan kolagen kelompok P1, P2, dan P3 tidak berbeda secara nyata ( $>>0,05)$, tetapi berbeda nyata dengan kelompok K- dan $\mathrm{K}+$. Kesimpulan dari penelitian ini adalah sugar dressing efektif untuk meningkatkan kepadatan kolagen pada proses penyembuhan luka bakar.
\end{abstract}

Kata kunci: sugar dressing, kolagen, kepadatan kolagen, luka bakar

Abstract

Burns are loss or damage to skin integrity due to exposure to temperature or $\mathrm{pH}$, chemicals, friction, pressure trauma, and radiation. The wound healing process cannot be separated from the role of collagen. Collagen synthesis can be promoted through the provision of sugar (sugar dressing). The purpose of this study was to determine the effectiveness of sugar dressings to increase the density of collagen in the healing process of artificial burns on the skin of male white rats (Rattus norvegicus). Twenty male white rats (Rattus norvegicus) were divided into five groups with the number of four each group. K-group (negative dick) is not given injury. The $K+$ group (positive control) is given injury and then only given physiological NaCl rinses. The Pl group (Bioplacenton $^{\circledR}$ ) was given a wound with Bioplacenton ${ }^{\circledR}$ treatment. Group P2 (sugar dressing) is given a wound with the treatment of sugar and P3 (honey) using honey as a medicine. Treatment is given every day for fourteen days. The Kruskal-Wallis nonparametric test results showed significant differences $(p<0,05)$ and continued with Mann-Whitney difference test. Collagen density groups P1, P2, and P3 were not significantly different ( $p>0,05)$, but were significantly different from the $K$ - and $K+$ groups. The conclusion of this study is that sugar dressing is effective to increase the density of collagen in the healing process of burns.

Key words: sugar dressing, collagen, density of collagen, burns 


\section{PENDAHULUAN}

Kulit sebagai pertahanan terluar dari tubuh lebih rentan untuk mengalami kerusakan, salah satunya adalah luka bakar. Luka bakar adalah kerusakan jaringan yang disebabkan oleh kontak dengan sumber panas, seperti air, api, bahan kimia, listrik dan radiasi (Balqis dkk., 2014). Luka bakar dapat terjadi pada hewan, namun kejadiannya jarang ditemui dalam praktik hewan kecil dan merupakan hasil dari paparan api yang disengaja ataupun tidak disengaja, luka bakar dari cairan atau gas panas, atau kontak dengan permukaan yang panas (Bohling, 2014 dan Pavletic, 2006 dalam Maravelis et al., 2015). Keberhasilan perawatan luka bakar bergantung pada pemahaman mengenai patofisiologi luka bakar lokal dan respon sistemik terhadap luka bakar. Perawatan luka bakar pada hewan merupakan adaptasi pengetahuan yang dikumpulkan dari kasus luka bakar yang terjadi pada manusia. Perawatan luka bakar mencakup tiga hal, yaitu pertolongan pertama, penanganan komplikasi sistemik dan penanganan luka bakar lokal (Maravelis et al., 2015).

Penanganan luka bakar harus dilakukan sesegera mungkin untuk menghindari terjadinya komplikasi yang ringan sampai berat. Perawatan luka bakar biasanya menggunakan obat topikal komersial seperti Bioplacenton ${ }^{\circledR}$. Selain itu, bahan alam seperti madu telah digunakan juga sebagai terapi luka bakar. Namun keduanya tidak selalu tersedia di sekitar kita. Mahalnya harga untuk obat komersial seperti Bioplacenton ${ }^{\circledR}$ dapat meningkatkan biaya perawatan luka bakar bagi pasien yang menderita luka bakar yang luas. Bioplacenton $^{\circledR}$ yang digunakan sebagai terapi luka bakar kurang mampu menyerap eksudat yang terbentuk akibat luka bakar. Madu yang digunakan sebagai terapi sebaiknya adalah madu asli yang harganya juga tidak murah. Alternatif dibutuhkan untuk mengurangi biaya perawatan luka bakar agar lebih murah dan bahannya mudah untuk didapatkan. Salah satu contohnya adalah gula untuk terapi luka bakar.

Sugar dressing merupakan pemanfaatan gula sebagai terapi luka yang telah digunakan sejak zaman dahulu (Biswas et al., 2010). Kandungan sukrosa dalam gula mampu memberikan efek osmotik yang berkaitan dengan aktivitas air $\left(\mathrm{a}_{\omega}\right)$ dalam luka untuk mengontrol tumbuhnya bakteri (Biswas et al., 2010) dan mampu mensekresi TGF- $\alpha$, menarik makrofag ke jaringan luka dan mengekspresikan reseptor integrin $\alpha_{2}$ dan $\beta_{1}$ yang berfungsi dalam proliferasi fibroblas dan sintesis kolagen (Nakao et al., 2006). TGF- $\alpha$, sebagai reseptor EGF, berperan sebagai aktivator EGF untuk mensintesis kolagen (Daehwan et al., 2015). Berdasarkan hal tersebut, penelitian mengenai efektivitas sugar dressing sebagai terapi luka bakar perlu dilakukan sebab gula merupakan produk alami yang mudah dan murah untuk didapatkan.

\section{METODE PENELITIAN}

\section{Alat dan Bahan}

Bahan yang digunakan pada penelitian ini yaitu 20 ekor tikus putih jantan (Rattus norvegicus) yang berumur tiga sampai empat bulan dengan berat badan 150-200 gram. Tikus dipelahara dalam kandang individu yang terbuat dari kayu. Kandang diberi sekam untuk menjaga suhu tetap optimal. Gula bubuk, madu, dan Bioplacenton ${ }^{\circledR}$ digunakan sebagai terapi luka bakar kemudian luka dibalut dengan kassa.

Peralatan yang digunakan pada penelitian ini yaitu pot pakan dan minum, silet untuk mencukur bulu tikus, plat stainless steel (luas 2,5 $\times 2,5 \mathrm{~cm}$ dengan ketebalan $1 \mathrm{~mm})$ untuk pembuatan luka bakar, spuit tuberculin (OneMed Health Care), cotton bud untuk pengaplikasian obat secara topikal, glove untuk menjaga tangan tetap steril, kapas, peralatan bedah minor untuk pengambilan jaringan kulit, serta mikroskop trinokuler Olymphus.

\section{Perlakuan}

Penelitian dilakukan menggunakan Rancangan Acak Lengkap (RAL). Tikus dibagi menjadi lima kelompok perlakuan, yaitu perlakuan K- (kontrol negatif) adalah kelompok tikus yang tidak diberi perlukaan, perlakuan $\mathrm{K}+$ (kontrol positif) merupakan kelompok tikus yang diberi perlukaan dengan bilasan $\mathrm{NaCl}$ fisiologi saja, perlakuan P1 (Bioplacenton ${ }^{\circledR}$ ) merupakan 
kelompok tikus yang diberi luka dengan pengobatan Bioplacenton ${ }^{\circledR}$, perlakuan P2 (sugar dressing) adalah kelompok tikus yang diberi luka dengan pengobatan gula, dan perlakuan P3 (madu) adalah kelompok tikus dengan perlukaan yang diobati dengan madu. Tiap perlakuan terdiri dari empat ekor tikus. Terapi dilakukan sebanyak sekali sehari selama 14 hari. Pengamatan akan dilakukan pada hari ke lima belas.

\section{Analisis Data}

Data dianalisis menggunakan SPSS Versi 22 meliputi uji nonparametrik Kruskal-Wallis kemudian uji lanjutan menggunakan uji MannWhitney $U$.

\section{HASIL DAN PEMBAHASAN}

Hasil gambaran histopatologi kulit tikus menunjukkan bahwa pada setiap kelompok perlakuan memiliki kepadatan kolagen yang berbeda-beda, seperti terlihat pada Gambar 1 dan Gambar 2. Gambaran histopatologi tersebut kemudian dikuantifikasi menggunakan aplikasi NIS-Elements BR 4.10.00. Hasilnya berupa persentase kepadatan kolagen setiap kelompok seperti yang disajikan pada Tabel 1. Kemudian data yang diperoleh diolah menggunakan uji nonparametrik Kruskal-Wallis seperti pada Tabel 2.

Tabel 2. menunjukkan rerata kepadatan kolagen pada setiap kelompok perlakuan. Kelompok kontrol negatif memiliki rerata kepadatan kolagen 84,59\% dengan simpangan baku 3,455. Kelompok kontol positif yang dibilas menggunakan $\mathrm{NaCl}$ fisiologis saja memiliki rerata kepadatan kolagen $78,46 \%$ dengan simpangan baku 2,452. Rerata kepadatan kolagen pada kelompok yang diberi Bioplacenton $^{\circledR} \quad$ sebesar $96,11 \%$ dengan simpangan baku 0,769. Kelompok P2 yang diberi sugar dressing memiliki rerata kepadatan kolagen sebesar $96,16 \%$ dengan simpangan baku 3,034. Pemberian madu pada kelompok P3 menunjukkan rerata kepadatan kolagen sebesar 97,17\% dengan simpangan baku 1,457 .
Uji Kruskal-Wallis menunjukkan perbedaan nyata secara signifikan sebesar $0,005(\mathrm{p}<0,05)$. Perbedaan setiap kelompok selanjutnya diuji dengan uji beda Mann-Whitney. Berdasarkan uji beda Mann-Whitney, kelompok kontrol positif $(\mathrm{K}+)$ memiliki perbedaan kepadatan kolagen secara signifikan terhadap kelompok K-, P1, P2, dan P3 ( $\mathrm{p}<0,05)$. Kelompok K- menunjukkan kepadatan kolagen yang lebih rendah jika dibandingkan dengan kelompok yang diberi Bioplacenton ${ }^{\circledR}$, sugar dressing, dan madu.

Kepadatan kolagen kelompok perlakuan $\mathrm{K}+$ pada penelitian ini memiliki persentase yang paling rendah diantara kelompok K- (kontrol negatif), P1 (Bioplacenton $\left.{ }^{\circledR}\right), \quad$ P2 $\quad$ (sugar dressing), dan P3 (madu). Hasil tersebut dapat terjadi karena $\mathrm{K}+$ (kontrol positif) merupakan kelompok perlakuan tikus yang diberi luka bakar kemudian dibilas dengan $\mathrm{NaCl}$ fisiologis. Natrium Klorida 0,9\% merupakan larutan isotonis aman untuk tubuh, tidak iritan, melindungi granulasi jaringan dari kondisi kering, menjaga kelembaban sekitar luka dan membantu menjalani proses penyembuhan. Prinsip $\mathrm{NaCl}$ fisiologis dalam perawatan luka berfungsi sebagai cairan yang mempertahankan kelembaban. Namun, $\mathrm{NaCl}$ fisiologis tidak dapat memberikan kelembaban dalam jangka waktu yang lama sehingga akan menimbulkan trauma rasa nyeri dan tidak memiliki efek mencegah kontaminasi bakteri pada luka (Dewi, 2014). Selain itu, $\mathrm{NaCl}$ fisiologis kurang mampu meningkatkan pembersihan jaringan luka dan mengurangi eksudat (Nurman, 2015).

Kepadatan kolagen kelompok K- (kontrol negatif) menunjukkan persentase yang lebih tinggi dibandingkan dengan kelompok $\mathrm{K}+$ (kontrol positif), namun lebih rendah dibandingkan kelompok P1 (Bioplacenton ${ }^{\circledR}$ ), P2 (sugar dressing), dan P3 (madu). Hasil tersebut dapat terjadi karena kelompok K- (kontrol negatif) merupakan kelompok tikus yang tidak diberi luka bakar. Persentase kepadatan kolagen pada kelompok K- menunjukkan kepadatan kolagen yang ada di kulit normal. Kolagen pada kulit normal merupakan penyatuan molekulmolekul tropokolagen menjadi fibril. Kemudian fibril-fibril mengalami cross-linking menjadi 
Tabel 1. Kepadatan kolagen pada seluruh kelompok

\begin{tabular}{cccccc}
\hline \multicolumn{7}{c}{ Kepadatan Kolagen (\%) } \\
Pengulangan & K- & K+ & P1 & P2 & P3 \\
\hline 1 & 87,72 & 76,68 & 96,03 & 97,57 & 99,09 \\
2 & 80,66 & 78,04 & 97,09 & 98,37 & 96,32 \\
3 & 87,26 & 82,04 & 95,21 & 97,04 & 97,47 \\
4 & 82,73 & 77,09 & 96,11 & 91,69 & 95,80 \\
\hline
\end{tabular}

Tabel 2. Rerata kepadatan kolagen pada tiap kelompok perlakuan

\begin{tabular}{lc}
\hline Perlakuan & Rerata(\%) \pm Simpangan baku \\
\hline K- (kontrol negatif) & $84,59^{\mathrm{b}} \pm 3,455$ \\
K+ (kontrol positif) & $78,46^{\mathrm{c}} \pm 2,452$ \\
P1 (Bioplacenton $\left.{ }^{\circledR}\right)$ & $96,11^{\mathrm{a}} \pm 0,769$ \\
P2 (sugar dressing) & $96,16^{\mathrm{a}} \pm 3,034$ \\
P3 (madu) & $97,17^{\mathrm{a}} \pm 1,457$ \\
\hline
\end{tabular}

Keterangan: Superskrip berbeda pada kolom yang sama menunjukkan perbedaan signifikan $(p<0,05)$

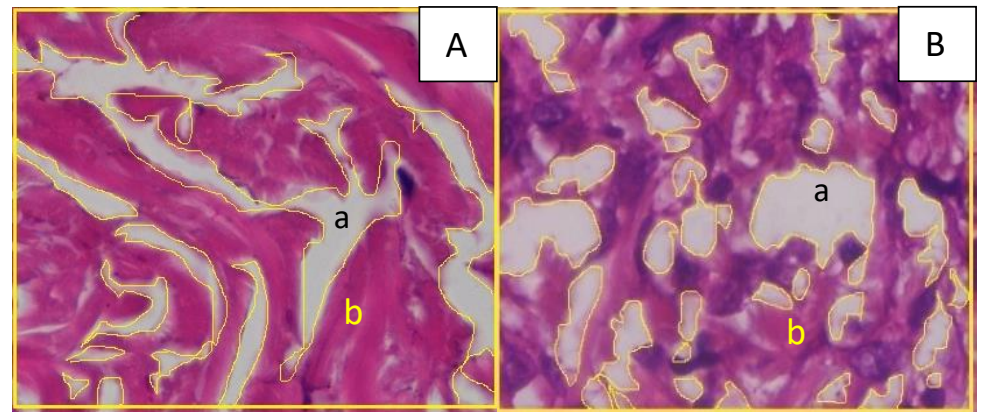

Gambar 1. Gambaran histopatologi kepadatan kolagen kelompok Kontrol. A. Kontrol Negatif (kulit normal). B. Kontrol Positif (tanpa terapi). Ruang kosong ditunjukkan dengan (a) dan kolagen ditunjukkan dengan (b).

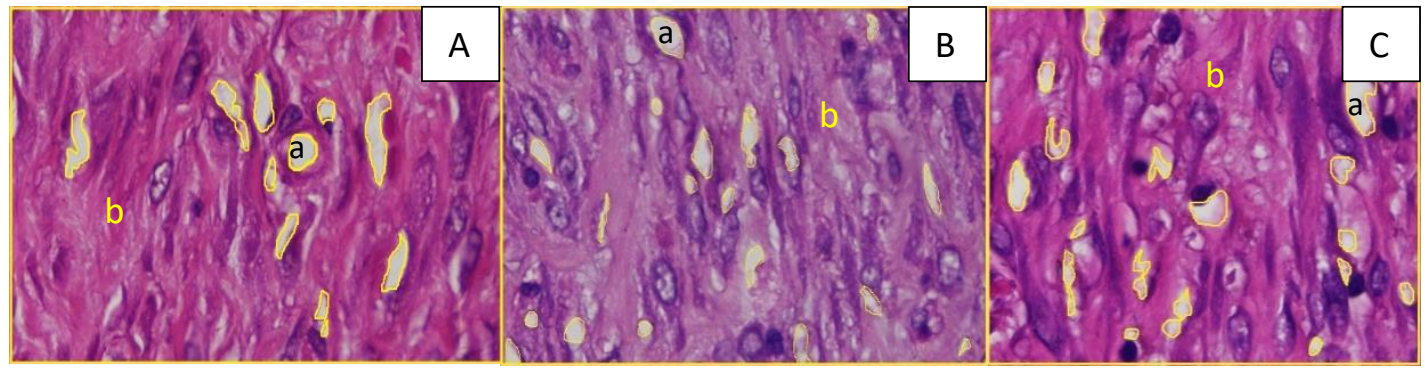

Gambar 2. Gambaran histopatologi kepadatan kolagen kelompok Perlakuan (P). A. P1 (terapi dengan Bioplacenton $\left.{ }^{\circledR}\right)$; B. P2 (terapi dengan sugar dressing); C. P3 (terapi dengan madu). Ruang kosong ditunjukkan dengan (a) dan kolagen ditunjukkan dengan (b).

bundle (Triyono, 2005). Sintesis kolagen dibutuhkan dalam jumlah banyak sebagai usaha untuk membangun kembali matriks ekstraseluler (ECM) yang rusak akibat jaringan rusak (McGavin and James, 2007). Sedangkan jaringan yang normal tidak membutuhkan perbaikan ECM karena tidak terjadi kerusakan.

Kepadatan kolagen P1 (Bioplacenton $^{\circledR}$ ) menunjukkan kepadatan yang lebih tinggi dibandingkan dengan kelompok $\mathrm{K}+$ dan $\mathrm{K}$-, namun memiliki persentase yang sama dengan 
P2 dan P3. Hasil tersebut dapat terjadi karena P1 merupakan kelompok perlakuan yang diberi luka bakar dengan pengobatan Bioplacenton ${ }^{\circledR}$. Bioplacenton $^{\circledR}$ merupakan obat topikal yang mengandung $10 \%$ ekstrak plasenta dan $0,5 \%$ neomisin sulfat (MIMS, 2016). Ekstrak plasenta dapat meningkatkan sintesis kolegen, meningkatkan protein jaringan, mempercepat neoangiogenesis, dan epitalisasi (Navadiya et al., 2012).

Efek penyembuhan dari ekstrak plasenta terutama dikaitkan dengan berbagai zat aktif biologis seperti peptida, faktor pertumbuhan, glikosaminoglikan, dan beberapa molekul kecil yang sangat dibutuhkan untuk pertumbuhan janin (Chakraborty et al., 2014). Hal ini terjadi karena ektrak plasenta diperkaya enzim-enzim, seperti alkalin dan asam fosfatase, GOT, juga diperkaya dengan RNA, DNA, dan ATP, vitamin $\left(\mathrm{B}_{1}, \mathrm{~B}_{2}, \mathrm{~B}_{6}\right)$, asam pantotenat, biotin, PABA, asam folat, $\mathrm{B}_{12}$, kolin, dan inositol. Ekstrak plasenta juga mengandung asam amino, asam lemak dan unsur-unsur seperti $\mathrm{Na}, \mathrm{K}, \mathrm{Ca}, \mathrm{Mg}$, $\mathrm{Cu}, \mathrm{Fe}, \mathrm{P}$, dan Si (Kanti et al., 2001). Sedangkan efek antibiotik diperoleh dari kandungan neomisin sulfat.

Neomisin sulfat adalah bentuk dari garam sulfat neomisin, antibiotik aminoglikosida spektrum luas yang berasal dari Streptomyces fradiae dengan aktivitas antibakteri. Neomisin merupakan antibiotik komplek yang terdiri dari tiga komponen, yaitu dua komponen isomerik B dan C (komponen aktif), dan neomisin A sebagai komponen minor. Neomisin secara ireversibel berikatan dengan protein $16 \mathrm{~S}$ rRNA dan S12 dari subunit ribosomal 30S bakteri. Sehingga perakitan komplek inisiasi antara mRNA dan ribosom bakteri terganggu yang berakibat pada terhambatnya inisiasi sintesis protein. Selain itu, neomisin menginduksi misreading pola mRNA dan menyebabkan translasi framshift sehingga menghasilkan penghentian secara prematur yang berakibat pada kematian sel bakteri (National Cancer Institute, 2018). Blancard et al. (2016) telah membuktikan kemampuan neomisin sulfat dalam meningkatkan aktivitas antimikrobial dari mupirocin. Neomisin sulfat dapat memediasi penghambatan fungsi $\mathrm{P}$ RNase dari suatu organisme yang berpartisipasi dalam jalur pemrosesan tRNA dan menjadi target utama dari mupirocin (Blancard et al., 2016).

Kepadatan kolagen kelompok P3 (madu) menunjukkan kepadatan kolagen yang sama dengan P1 dan P2, namun lebih tinggi dibandingkan dengan $\mathrm{K}+$ dan $\mathrm{K}$-. Hasil tersebut dapat terjadi karena madu mengandung beberapa zat yang berperan dalam penyembuhan luka, seperti gula dan hidrogen peroksida (Alam et al., 2014) serta kemampuannya untuk menginduksi TGF- $\beta$ (Lee et al., 2011). Kandungan gula dan hidrogen peroksida sebagai antibakteri melalui efek osmotik yang akan menciptakan lingkungan yang tidak menguntungkan untuk pertumbuhan dan pertahanan hidup mikroorganisme. Hidrogen peroksida dapat menghambat pertumbuhan bakteri dan mampu menstimulasi proliferasi fibroblas (Alam et al., 2014). Madu mampu meningkatkan fase remodeling melalui matriks metalloproteinase dan TGF- $\beta$ yang terlibat dalam reorganisasi matriks ekstraseluler (ECM) dan deposisi kolagen (Lee et al., 2011).

Kepadatan kolagen kelompok P2 (sugar dressing) menunjukkan kepadatan kolagen yang sama dengan P1 dan P3, namun lebih tinggi dibandingkan dengan $\mathrm{K}+$ dan $\mathrm{K}-$. Hasil tersebut dapat terjadi akibat kandungan sukrosa pada gula yang mampu menurunkan aktivitas air dalam jaringan luka sebagai efek antibakteri, menarik makrofag ke jaringan luka, mensekresi aktivator plasminogen tipe urokinase (u-PA), sintesis TGF- $\alpha$ dan mengekspresikan reseptor integrin $\alpha_{2}$ dan $\beta_{1}$ untuk meningkatkan sintesis kolagen dari fibroblas (Nakao et al., 2006). Gula dapat meningkatkan migrasi keratinosit dan fibroblas ke jaringan yang rusak, pembentukan matriks ekstraseluler (ECM) baru, reepitalisasi dan pembentukan jaringan granulasi (Nakao et al., 2006).

Efek osmotik pada gula dipengaruhi oleh aktivitas air. Aktivitas air $\left(\mathrm{a}_{\omega}\right)$ dalam jaringan sangat dibutuhkan bakteri untuk tumbuh dan berkembang biak. Aktivitas antimikroba dari gula berasal dari kemampuan gula untuk menciptakan lingkungan yang aktivitas airnya $\left(\mathrm{a}_{\omega}\right)$ rendah yang akan menghambat pertumbuhan bakteri. Hal ini telah dibuktikan 
dalam penelitian yang dilakukan oleh Chirife $e t$ al. (1983). Aktivitas air yang rendah juga berarti tekanan osmotiknya tinggi. Pemberian konsentrasi gula yang sangat tinggi pada setiap awal perawatan akan meningkatkan akitivitas air $\left(\mathrm{a}_{\omega}\right)$ karena pengambilan air dari jaringan di sekitarnya. Kemudian nilai $\mathrm{a}_{\omega}$ akan turun drastis karena penambahan gula di tempat luka. Perubahan $\mathrm{a}_{\omega}$ yang mendadak dapat menyebabkan kematian sel (Chirife et al., 1983). Osmolaritas tinggi yang dimiliki gula lebih besar daripada plasma sehingga dapat mengurangi edema lokal dengan cepat. Tekanan osmotik yang kuat ini mampu menstimulasi pertumbuhan jaringan granulasi dan pembersihan area luka (César et al., 2013). Pembersihan daerah luka juga dipengaruhi oleh makrofag pada jaringan luka untuk fagositosis mikroba (Arimbi dkk., 2015).

Pemberian gula sebagai terapi dapat menarik makrofag ke jaringan luka (Nakao et al., 2006). Makrofag berfungsi sebagai fagositosis dan sintesis berbagai faktor pertumbuhan, seperti FGF, TGF- $\beta$, dan EGF (Triyono, 2005). Fagositosis dalam jaringan luka dapat membersihkan luka dari bakteri dan jaringanjaringan yang mati (Arimbi dkk., 2015). Sintesis berbagai faktor pertumbuhan, salah satunya EGF, dapat mempromosikan penyembuhan luka dengan mengganti jaringan yang rusak (Triyono, 2005).

EGF merupakan salah satu faktor pertumbuhan yang hadir dengan konsentrasi yang tinggi selama tahap awal penyembuhan luka. EGF meningkatkan epitalisasi luka dan mengurangi jaringan parut dengan mencegah kontraksi luka yang berlebih. EGF memiliki 30\% asam amino yang homolog dengan TGF- $\alpha$. Reseptor EGF (EGFR) akan teraktivasi oleh beberapa ligan, termasuk TGF- $\alpha$ dan heparinbinding EGF (Bilska et al., 2003).

TGF- $\alpha$ (transforming growth factor- $\alpha$ ), secara struktural homolog dengan EGF (epidermal growth factor). Hal ini dapat terjadi akibat mediasi dari reseptor yang sama yang mengikat EGF (Koyama dan Daniel, 1989). Reseptor EGF (EGFR) adalah reseptor tirosin kinase yang dapat diaktifkan oleh beberapa ligan, termasuk TGF- $\alpha$ (Bilska et al., 2003). Gula dapat mempromosikan produksi TGF- $\alpha$ dari keratinosit pada jaringan luka. TGF- $\alpha$ kemudian diaktivasi oleh reseptor integrin $\alpha_{2}$ dan $\beta_{1}$ untuk dapat mengkativasi EGF (Chen et al., 1993).

TGF- $\alpha$ menjadi pengatur autokrin/parakrin yang penting dari u-PA keratinosit yang dapat mengatur respon keratinosit terhadap luka yang meliputi peningkatan ekspresi, migrasi, dan proliferasi u-PA (Jensen \& Ulrich, 1993). Aktivator plasminogen tipe urokinase (u-PA) merupakan salah satu dari dua tipe enzim yang mengaktifkan plasminogen dan teridentifikasi pada semua spesies mamalia. Enzim ini tidak ditemukan dalam struktur kulit normal, namun pada kulit yang mengalami perlukaan akan ditemukan setelah 12 jam dalam keratinosit (Hansen et al., 1988) dan terlibat dalam migrasi keratinosit yang terjadi selama penyembuhan luka (Morioka et al., 1987). Aktivator plasminogen tipe urokinase (u-PA) berperan dalam pertumbuhan tubuh dan fungsi lainnya, seperti enzim yang paling bertindak sebagai enzim utama dalam pemecahan protein matriks ekstraseluler (ECM) dalam berbagai proses termasuk migrasi sel dan degradasi atau remodeling jaringan.

Pergerakan keratinosit yang meningkat ke daerah luka oleh rangsangan TGF- $\alpha$ dan u-PA dapat meningkatkan produksi TGF- $\alpha$. TGF- $\alpha$ kemudian teraktivasi oleh reseptor integrin $\alpha_{2}$ dan $\beta_{1}$ untuk dapat mengkativasi EGF hasil sintesis dari makrofag. EGF yang aktif akan menstimulasi kontraksi dan migrasi fibroblas ke jaringan luka kemudian fibroblas mensintesis kolagen. Regenerasi kolagen pada proses penyembuhan dipengaruhi oleh MMP dan u-PA (dikontrol oleh TGF- $\alpha$ ) untuk degradasi kolagen (Chen et al., 1993).

\section{KESIMPULAN}

Sugar dressing mampu meningkatkan kepadatan kolagen dibandingkan dengan tikus yang tidak diberi terapi. Efektivitas gula dalam meningkatkan kepadatan kolagen pada proses penyembuhan luka bakar dibuktikan dengan 
hasil yang tidak berbeda nyata dengan kelompok yang diberikan Bioplacenton ${ }^{\circledR}$ dan madu.

\section{UCAPAN TERIMA KASIH}

Peneliti mengucapkan terima kasih kepada PSDKU Banyuwangi Universitas Airlangga atas izin yang diberikan dan fasilitas untuk melaksanakan penelitian.

\section{DAFTAR PUSTAKA}

Alam, F.M.D., A. Islam, S.H. Gan, and M.D.I. Khalil. 2014. Honey: A Potential Therapeutic Agent for Managing Diabetic Wounds. Evid. Based Complement Alternat. Med, 2014.

Arimbi, A. Azmijah, R. Darsono, H. Plumeriastuti, T.V. Widiyanto, dan D. Legowo. 2015. Buku Ajar: Patologi Umum Veteriner. Edisi 2. Airlangga University Press. Surabaya.

Balqis, U., R. Marwiyah. 2014. Gambaran Histopatologis Penyembuhan Luka Bakar Menggunakan Daun Kedondong (Spondias dulcis F.) dan Minyak Kelapa pada tikus Putih (Rattus norvegicus). Jurnal. Program Studi Pendidikan Dokter Hewan Fakultas Kedokteran Universitas Syah Kuala. Banda Aceh.

Bilska, T. Anna, Grazul, M.L. Johnson, J.J. Bilski, D.A. Redmer, L.P. Reynolds, A. Abdullah, and K.M. Abdullah. 2003. Wound Healing: The Role of Growth Factors. Drugs of Today, 39(10): 787-800.

Biswas, A., M. Bharara, C. Hurst, R. Gruessner, D. Armstrong, and H. Rilo. 2010. Journal of Diabetes Science and Thechnology: Use of Sugar on the Healing of Diabetic Ulcers: A Review. Symposium. Diabetes Tech Soc, 4(5): 1139-1145.

Blanchard, C., L. Brooks, A. Beckly, J. Colquhoun, S. Dewhurst, and P.M. Dunman.
2016. Neomycin Sulfate Improves the Antimicrobial Activity of Mupirocin-Based Antibacterial Ointments. Am Soc Microbiol, 60(2): 862-872.

César, M.V., I. A. Arango, C.S. Perna, and M.A.M. Cubiles. 2013. Importance of Sucrose for Healing Infected Wound. Revita Cubana de Medicina Militar, 42(1).

Chakraborty, P.D., S. Goswani, S. Bera, and I. Mukhopadhyay. 2014. Quantitation of Polydeoxyribonucletides (PDRNs) in Human Placental Extract by Fluorescence Spectroscopy Using Ethidium Bromide. Am $J$ Analytic Chem, 5: 784-795.

Chen, J.D., J.P. Kim, K. Zhang, Y. Sarret, K.C. Wynn, R.H. Kramer, and D.T. Woodley. 1993. Epidermal Growth Factor (EGF) Promotes Human Keratinocyte Locomotion on Collagen by Increasing The Alpha 2 Integrin Subunit. Experimental Cell Research, 209(2): 216-223.

Chirife, J., L. Herszage, A. Joseph, and E.S. Kohn. 1983. In Vitro Study of Bacterial Growth Inhibition in Concentrated Sugar Solutions: Microbiological Basis for the Use of Sugar in Treating Infected Wounds. Am Soc Microbiol, 23(5): 766-773.

Daehwan, K., S.Y. Kim, S.K. Mun, S.M. Rhee, and B.J. Kim. 2013. Epidermal Growth Factor Improves The Migration and Contractility of Aged Fibroblast Cultured on 3D Collagen Matrices. Int J Mol Med, 35(4): 1017-1025.

Dewi, I.A.S.S.K. 2014. Perbedaan Efektifitas Epitelisasi Antara Perawatan Terbuka Menggunakan Moist Exposed Burn Ointment dengan Perawatan Tertutup Menggunakan $\mathrm{NaCl}$ 0,9\% pada Luka Bakar Derajat II di Rumah Sakit Umum Daerah Dr. Moewadi Surakarta [Tesis]. Program Studi Magister Kesehatan Keluarga Minat Utama 
Pendidikan Ilmu Bedah Universitas Sebelas Maret. Surakarta.

Hansen, J.G., L.R. Lund, R. Elisabeth, V. Ottevanger, and D. Keld. 1988. Urokinaseand Tissue- Type Plasminogen Activators in Keratinocytes During Wound Reepithelialization In Vivo. Soc Investigat Dermatol, 90(6): 790-795.

Jensen, P.J. and U. Rodeck. 1993. Autocrine/Paracrine Regulation of Keratinocyte Urokinase Plasminogen Activator Through The TGF- $\alpha / E G F$ Receptor. J Cell Physiol, 155(2).

Kanti, B.T., A. Biswajit, B.P. Natai, B. Subhashree, and M. Biswapati. 2001. Wound Healing Activity.

Koyama, S.Y., and D.K. Podolsky. 1989. Differential Expression of Transforming Growth Factor $\alpha$ and $\beta$ in Rat Intestinal Epithelial Cells. Am Soc Clin Investigat, 83: 1768-1773.

Lee, D.S., S. Sinno and A. Khachemoune. 2011. Honey and Wound Healing. Am J Clin Dermatol, 12(3): 181-190.

Maravelis, G., A. Voutsinou, N. Tsampa, and L.G. Papasoglon. 2015. Management of An Extensive Partial and Full Thickness Skin Burn in A Dog with The Aid of Medical Honey. Hellenic J Companion Animal Med, 4(2): 35-40.

McGavin \& James, M. Donald and F.Z. James. 2007. Pathologic Basis of Veterinary Disease. $4^{\text {th }}$ Ed. Mosby Elsevier.

MIMS. 2016. Bioplacenton. MIMS (C) 2016. // http://www.mims.com/myanmar/drug/info/bi oplacenton?type=full [31 Maret 2018].
Morioka, S., G.S. Lazarus, J.L. Baird, and P.J. Jensen. 1987. Migrating Keratinocytes Express Urokinase-Type Plasminogen Activator. Society Investigat Dermatol, 88(4): 418-423.

Nakao, H., M. Yamazaki, R.T.H. Ogawa. 2006. Mixture of Sugar and Povidone-Iodine Stimulates Wound Healing by Activaitng Keratonocytes and Fibroblast Function. Arch Dermatol Res, 298: 175-182.

National Cancer Institute. 2018. Neomycin Sulfate (Code C66227). Department of Health and Human Services, National Cancer Institute. USA./ /https://ncit.nci.nih.gov/ncitbrowser/Concept Report.jsp?dictionary=NCI_Thesaurus\&ns= ncit\&code $=$ C66227 [30 Maret 2018].

Navadiya, S.K., Y.L. Vaghani, and M.P. Patel. 2012. Study of Topical Placental Extract Versus Povidone Iodine and Saline Dressing in Various Diabetic Wounds. Departement of General Surgery, Surat Municipal Institute of Medical Education and Research (SMIMER). Surat. Nat J Med Res, 2(4): 411413.

Nurman, M. 2015. Perbandingan Efektifitas $\mathrm{Madu}+\mathrm{Nacl}$ 0,9\% dengan $\mathrm{NaCl}$ 0,9\% saja Terhadap Penyembuhan Luka Gangren pada Pasien Diabetes Mellitus Tipe II di Wilayah Kerja Puskesmas Bangkinang Kota Tahun 2015. Jurnal Keperawatan STIKes Tuanku Tambusai. Hal.1-11.

Triyono, B. 2005. Perbedaan Tampilan Kolagen di Sekitar Luka Insisi pada Tikus Wistar yang Diberi Infiltrasi Penghilang Nyeri Levobupivakain dan yang Tidak Diberi Levobupivakain [Tesis]. Program Magister Biomedik dan PPDS I Universitas Diponegoro. Semarang. 